\title{
Somatotropic Dysfunction in Growth Hormone-Releasing Hormone-Deprived Neonatal Rats: Effect of Growth Hormone Replacement Therapy ${ }^{1}$
}

\author{
SILVANO G. CELLA, VITO DE GENNARO COLONNA, VITTORIO LOCATELLI, \\ GILBERTO E. BESTETTI, GIAN LUIGI ROSSI, ANTONIO TORSELLO, \\ WILLIAM B. WEHRENBERG, AND EUGENIO E. MÜLLER
}

Department of Pharmacology, Chemotherapy and Toxicology, University of Milan, 20129 Milan, Italy |S.G.C., V.d.G.C., V.L., A.T., E.E.M.]; Institut für Tierpathologie, Universität Bern, CH.3001 Bem, Switzerland /G.E.B., G.L.R.]; Department of Health Sciences, University of Wisconsin, Milwaukee, Wisconsin 53201 (W.B.W.)

\section{ABSTRACT}

\begin{abstract}
In a previous work, we reported that passive immunization with anti-growth hormone-releasing hormone (GHRH) antibodies (GHRH-Ab) in neonatal rats caused disruption of somatotropic function that was still present $60 \mathrm{~d}$ posttreatment. We studied the reversibility of this condition by growth hormone $(\mathrm{GH})$ replacement therapy. Neonatal rats received GHRH-Ab $(50 \mu \mathrm{L} /$ rat, s.c.) or normal rabbit serum every second day from birth up to postnatal $\mathrm{d} 10$ and received $\mathrm{hGH}$ $(0.4 \mu \mathrm{g} / \mathrm{g}$ body weight, s.c., b.i.d.) or vehicle in a $2 \times 2$ factorial design. Animals were studied on d 11 of age. In GHRH-Abtreated rats, GH therapy $l$ ) counteracted the reduced body weight and low plasma IGF-I levels; 2) failed to modify the reduced pituitary weight and GH content; 3) further reduced the low plasma $\mathrm{GH}$ levels; 4) partially restored the defective $\mathrm{GH}$ responsiveness to GHRH; 5) failed to modify the reduced hypothalamic somatostatin and increased GHRH gene expression in the hypothalamus; and 6) reverted the decreased pituitary somatostatin binding. Morphologic and morphometric evaluation of the pituitary gland from GHRH-Ab+GH pups showed that the number of GH-labeled structures was lower
\end{abstract}

than in normal rat serum-GH-treated pups, whereas the total GH immunoreactivity per unit surface, an index of intracellular hormone concentration, was slightly higher than in vehicle-GH or GHRH-Ab pups. As determined by electron microscopy, somatotropes from GHRH-Ab+GH pups had morphologic features of high cellular activity. It appears that in GHRH-deprived pups GH replacement therapy can normalize most but not all altered indices of the somatotropic function. The effects of GH are mainly directed at the pituitary, whereas the sensitivity of the hypothalamus to $\mathrm{GH}$ replacement is lower. (Pediatr Res 36: 315-322, 1994)

GH, growth hormone

GHRH, growth hormone-releasing hormone

GHRH-Ab, anti-GHRH-antibodies

NRS, normal rabbit serum

dCTP, deoxycytidine triphosphate

PRL, prolactin

SS, somatostatin
Recent studies by us $(1,2)$ and by other groups $(3,4)$ have shown that rat pups treated with GHRH-Ab may represent a suitable animal model for the study of the human growth disorders caused by a primary hypothalamic dysfunction. Neonatal administration of GHRH-Ab permanently inhibits the growth rate and alters several indices of the hypophyseal somatotropic function (1).

Received November 11, 1993; accepted March 21, 1994.

Correspondence and reprint requests: Eugenio E. Müller, MD, Department of Pharmacology, Chemotherapy and Toxicology, University of Milan, via Vanvitelli 32, 20129 Milan, Italy.

Supported by a grant from Kabi Pharmacia, Italy.

'This study was executed under the auspices of the Italian Society of Endocrinology, GH Study Group.
It is presently unknown whether these changes are due to the GHRH deficiency itself or to the consequent reduction of GH secretion. Therefore, we studied the effects of concomitant GH and GHRH-Ab treatment. We have administered GH daily to GHRH-deprived and control pups from postnatal $\mathrm{d} 1$ to 10 and subsequently evaluated in vivo and in vitro several hypothalamic and pituitary indices of somatotropic activity.

\section{METHODS}

All procedures were reviewed and approved by the ethical committee of the Department of Pharmacology of the University of Milan. 


\section{Functional Studies}

Animals. Pregnant Sprague-Dawley rats (Charles River, Calco, Italy) were purchased and housed under controlled conditions $\left(22 \pm 2^{\circ} \mathrm{C}, 65 \%\right.$ humidity, and artificial light from 0600 to $2000 \mathrm{~h}$ ). After birth, all litters were culled to a standard size of 12 pups and left with dams during the experimental period (see below). Studies were conducted on d 11 of age. In all, 250 pups were used.

Antiserum to GHRH. The GHRH-Ab was prepared by immunizing rabbits with a mixture of synthetic rat GHRH (5) and methylated BSA emulsified in Freund's adjuvant, as previously described (6). The biologic efficacy of the antiserum was assessed at various levels. The GHRH-Ab has repeatedly been shown to significantly inhibit $\mathrm{GH}$ secretion and growth $(3,4,7)$. In addition, the antiserum was tested for rat GHRH-binding capacity with ${ }^{125} \mathrm{I}$ labeled rat GHRH. The antiserum dilution required to bind $30 \%$ of the tracer was approximately 1:30 000. Characterization of the antiserum showed that it was directed toward the GHRH carboxy terminal. It cross-reacted with synthetic human, bovine, and porcine GHRH by less than $4 \%$, and the dose-response curves were not parallel with rat GHRH.

The antiserum did not cross-react with peptides that have considerable sequence homology with GHRH, including secretin, glucagon, vasoactive intestinal peptide, gastrin, motilin, bradykinin, and angiotensin.

Treatments. Each single litter was divided randomly into two groups, one of which was given GHRH-Ab (50 $\mu \mathrm{L} /$ rat, s.c.) starting on $\mathrm{d} 1$ and then on $\mathrm{d} 2,4,6,8$, and 10; the other group was given equal amounts of NRS. Each group, in turn, was divided into two subgroups, which were given twice daily (at 0900 and $1900 \mathrm{~h}$ ) hGH (Genotropin, Kabi Vitrum, Stockholm, Sweden, batch $870301,0.4 \mu \mathrm{g} / \mathrm{g}$ body weight, s.c.) diluted in normal saline or equal amounts of normal saline from $\mathrm{d} 1$ to 10 . All experiments were performed on d 11 , at $0900 \mathrm{~h}$, i.e. 14 $\mathrm{h}$ after the last $\mathrm{GH}$ injection.

Effect of acute GHRH. At 0830 to $0900 \mathrm{~h}$, the freemoving 11-d-old rats were injected with GHRH (human GHRH-44, Sanofi, Paris, France, batch DADJ01) at the dose of $0.2 \mu \mathrm{g} / \mathrm{kg}$ body weight, s.c. and were killed $15 \mathrm{~min}$ later. Trunk blood was collected into EDTA-containing tubes. Plasma samples and anterior pituitaries were stored frozen until GH was determined by RIA, as previously described (8). In this study, about 50 pups were used.

IGF-I RIA. Plasma IGF-I concentrations were evaluated by a homologous RIA in plasma extracted with $2 \mathrm{~N}$ $\mathrm{HCl}, 12.5 \%$, plus $87.5 \%$ ethanol, using reagents provided by National Hormone and Pituitary Program (NHPP). The sensitivity of the assay was $100 \mathrm{pg} / \mathrm{mL}$; intra- and interassay variabilities were less than $10 \%$. The plasma levels of IGF-I of eight pups for each experimental group were determined.

Pituitary GH gene expression. For the evaluation of $\mathrm{GH}$ mRNA levels, 12 pituitaries from each experimental group were collected in pools of three samples (four pools per experimental group), immediately frozen on dry ice, and stored at $-70^{\circ} \mathrm{C}$ until used. Total RNA was obtained by single-step acid guanidium-phenol-chloroform extraction (9). Total RNA samples $(20 \mu \mathrm{g} / \mathrm{sample})$ were electrophoresed on $1.2 \%$ formaldehyde-agarose gel and transferred to a nitrocellulose membrane (Schleicher \& Schuell, Dassel, Germany) at room temperature for $24 \mathrm{~h}$ in $10 \times \operatorname{SSC}(1 \times \mathrm{SSC}=0.1 \mathrm{M}$ sodium chloride $/ 0.01 \mathrm{M}$ sodium citrate). Filters were hybridized with a rat $\mathrm{GH}$ cDNA sequence kindly provided by Dr. Frances DeNoto (University of California, San Francisco, CA). The probe was labeled using the Megaprime DNA labeling system (Amersham, Little Chalfont, UK) with $\left[\alpha-{ }^{32} \mathrm{P}\right] \mathrm{dCTP}$ to a sp act of $1 \times 109 \mathrm{dpm} / \mu \mathrm{g}$ DNA. Control of the homogeneity of the amount of RNA loaded was performed by reprobing the filters with $\left[\alpha-{ }^{32} \mathrm{P}\right] \mathrm{dCTP}$-labeled $\beta$-actin cDNA. After hybridization, autoradiography was carried out at $-70^{\circ} \mathrm{C}$ for $24 \mathrm{~h}$ in the presence of an intensifying screen using Hyperfil-MP (Amersham). Quantification of the hybridization signal was performed on a scanning densitometer (LKB XL Laser Densitometer, LKB, Uppsala, Sweden). Pituitary GH mRNA levels were expressed as a percentage of the control values.

Pituitary SS binding. The anterior pituitary glands of seven pups for each experimental group were excised and frozen in liquid nitrogen. The SS autoradiography was performed on 14- $\mu \mathrm{m}$-thick, slide-mounted frozen sections as described by McCarthy and Plunkett (10). Due to the limited amount of tissue, only two concentrations of [ $\left.{ }^{125} \mathrm{I}\right] \mathrm{Tyr}{ }^{1}-\mathrm{SS}(2000 \mathrm{Ci} / \mathrm{mmol}$, Amersham) were used. One was $0.4 \mathrm{nM}$, near the receptor $\mathrm{k}_{\mathrm{d}}$, and the other was 0.8 $\mathrm{nM}$, a saturating concentration for the receptors (11). Nonspecific binding was determined with $10 \mu \mathrm{M}$ unlabeled SS (Sigma Chemical Co., St. Louis, MO). Sections were apposed to $\left[{ }^{3} \mathrm{H}\right]$ Hyperfilm (Amersham), exposed for $3 \mathrm{~d}$ at $-20^{\circ} \mathrm{C}$, and quantified by using a computer-assisted image analyzer. The results were expressed in arbitrary densitometry units.

Hypothalamic GHRH and SS gene expression. Hypothalami of the same pups used for pituitary GH mRNA expression were collected. The ablated areas extended from the optic chiasm to the mamillary bodies and laterally to the fornix. They were collected in pools of two samples, immediately frozen on dry ice, and stored at $-70^{\circ} \mathrm{C}$ until used. The total RNA was isolated from pooled hypothalamic tissue as alluded to previously (9). The total RNA samples $(20 \mu \mathrm{g} / \mathrm{sample})$ were spotted onto nitrocellulose sheets (BA 85, $0.45 \mu \mathrm{m}$, Schleicher \& Schuell; prewetted with $5 \times$ SSC) using a slot-blot apparatus (Minifold II, Schleicher \& Schuell). Filters were hybridized with a rat GHRH cDNA (plasmid prGRF 2, kindly provided by Dr. Kelly E. Mayo, Northwestern University, Evanston, IL) and rat SS cDNA (plasmid pSR-1, kindly provided by Dr. Richard H. Goodman, Oregon Health Center, Portland, OR). Specificity of hybridization of these probes has already been tested (12, $13)$. Both cDNA probes were labeled with $\left[\alpha{ }^{3}{ }^{32} \mathrm{P}\right] \mathrm{dCTP}$ 
as previously described for $\mathrm{GH}$ gene expression. Control of the homogeneity of the amount of RNA loaded was performed by reprobing the filters with $\left[\alpha-{ }^{32} \mathrm{P}\right] \mathrm{dCTP}$ labeled $\beta$-actin cDNA. Autoradiography was carried out at $-70^{\circ} \mathrm{C}$ for $24-72 \mathrm{~h}$ with an intensifying screen (see above). Quantification of the hybridization signal was performed as previously described, and the results were expressed as the percent of the control values.

Plasma and pituitary GH. Plasma and pituitary GH content were determined in six to 10 pups for each treatment group by a double antibody RIA (14). Results are expressed as $\mathrm{ng} / \mathrm{mL}$ and $\mu \mathrm{g} /$ pituitary in terms of the National Institutes of Health standard rat GH RP-2, the potency of which was $2.0 \mathrm{IU} / \mathrm{mg}$. The sensitivity of the assay was 0.5 $\mathrm{ng} / \mathrm{mL}$; intraassay variability was $5 \%$. To avoid possible interassay variation, all samples of a given experiment were assayed in a single assay.

\section{Morphologic, Morphometric, and Densitometric Studies}

General. Groups and treatments were as described above for the functional study. Six rats per group were used. Under intraperitoneal ketamine hydrochloride anesthesia, whole-body perfusion-fixation was performed as previously described (15).

Tissue processing. The brain was removed from the skull and weighed. After extraction from the basal meninges, the pituitary gland was weighed (Table 1) and cut longitudinally in half along the sagittal axis; a $0.5-\mathrm{mm}$ thick frontal slice was cut from each half at the level of the maximal pituitary height to yield two standard tissue blocks per animal, one for conventional, the other for immunocytochemical studies, as previously described (16). Tissue blocks for conventional microscopy were postfixed with $2 \%$ phosphate buffered $\left(\mathrm{pH} \mathrm{7.4)} \mathrm{OsO}_{4}\right.$, those for immunocytochemistry were not postfixed.

After dehydration, infiltration, and embedding in Spurr's low viscosity medium, semithin sections $(1.5 \mu \mathrm{m})$ were cut. Sections of each pituitary gland were stained with toluidine blue for light microscopic study. The immunocytochemical labeling of the hormones was performed by the peroxidase-antiperoxidase method, as previously described (15). We used rabbit anti-human GH and rabbit anti-human PRL (Dako Corp., Santa Barbara, CA), both diluted 1:200. These commercially available antisera are known to have negligible cross-reactivity for other hormones. The immunoreaction specificity was evaluated by either omitting the primary antiserum or preadsorbing it with $10 \mu \mathrm{g} / 100 \mu \mathrm{L}$ PBS purified rat GH or PRL (UCB-Bioproducts, Brussels, Belgium) (17).

Furthermore, on one section per animal the antiproliferating cell nuclear antigen (PCNA, BioGenex, San Ramon, CA) immunocytochemical reaction was performed to detect mitotic processes. The reaction was revealed by a biotin-streptavidin-alkaline phosphatase supersensitive detection system (BioGenex) (18).

Thin sections $(60 \mathrm{~nm})$ containing the entire hemipituitary profile were then cut from postfixed and nonpostfixed blocks for the electron microscopic studies. Sections from postfixed tissue were conventionally stained for contrast by uranyl acetate and lead citrate. The immunocytochemical GH labeling was performed according to a previous protocol (16) modified as follows: no etching, incubation in rabbit anti-human GH (Dako Corp.) 1:200 for $1 \mathrm{~h}$, incubation with goat anti-rabbit IgG conjugated to $15-\mathrm{nm}$ colloidal gold particles (IG; Janssen Life Science Products, Beerse, Belgium) diluted 1:40 in PBS-Tween-20 1:200, and washing in PBS-Tween-20 1:200. All thin sections were examined using a Zeiss EM-902 PC (Carl Zeiss, Zurich, Switzerland) at $80 \mathrm{kV}$.

Densitometry. Densitometry was performed using a video-based, computer-linked system programmed to identify and measure OD in the selected images. Screen displays of the amount of the immunoreactive substance in gray tones as well as the automatic measuring and evaluation of particles whose gray tone distinguished them clearly from the background were the main functions of the program. Furthermore, the interactive editing of images allowed elimination of artifacts.

The immunoreactive material in the semithin sections was quantified as previously described (19), with modifications: the light setting was 200 lux and the images were taken by a $40 \times$ objective. In one standard frontal hemisection, the immunohistochemically labeled cytoplasmic portions of somatotrophs and lactotrophs were measured.

The following measurements were obtained: 1 ) number of immunocytochemically labeled anatomical structures, which roughly corresponds to the cell number; 2) total

Table 1. Body and pituitary weight and GH content in 11-d-old pups given NRS or GHRH-Ab and saline or GH replacement therapy

\begin{tabular}{|c|c|c|c|c|c|}
\hline \multirow[b]{2}{*}{ In vivo treatment* } & \multirow[b]{2}{*}{ Body wt (g) } & \multicolumn{2}{|c|}{ Pituitary weight } & \multicolumn{2}{|c|}{ GH content } \\
\hline & & $\mathrm{mg}$ & $\mathrm{mg} / \%$ body wt & $\mu \mathrm{g} /$ pituitary & $\mu \mathrm{g} / \mathrm{mg}$ pituitary \\
\hline NRS + saline & $19.1 \pm 0.3$ & $2.1 \pm 0.07$ & $11.0 \pm 0.4$ & $18.8 \pm 1.8$ & $8.9 \pm 0.8$ \\
\hline NRS + GH & $21.5 \pm 1.0 \dagger$ & $2.1 \pm 0.1$ & $9.7 \pm 0.3$ & $17.8 \pm 0.8$ & $8.6 \pm 0.6$ \\
\hline GHRH-Ab + saline & $17.6 \pm 0.5 \dagger$ & $1.2 \pm 0.04 \ddagger$ & $7.0 \pm 0.3 \neq$ & $11.2 \pm 0.2 \ddagger$ & $9.1 \pm 0.4$ \\
\hline GHRH-Ab + GH & $18.3 \pm 0.4$ & $1.3 \pm 0.1 \ddagger$ & $7.2 \pm 0.6 \ddagger$ & $11.2 \pm 1.5 \ddagger$ & $9.2 \pm 1.7$ \\
\hline
\end{tabular}

* NRS or GHRH-Ab $(50 \mu \mathrm{L} / \mathrm{rat})$ was injected s.c. on d $1,2,4,6,8$, and 10 of age. GH (0.4 $\mu \mathrm{g} / \mathrm{g}$ body wt) was injected s.c. twice daily from d 1 to 10 . Each value is the mean \pm SEM of six to 10 determinations made in duplicate. The same description applies to subsequent tables. See text for details.

$+p<0.05$ vs NRS + saline value.

$\ddagger p<0.01$ vs NRS + saline value. 
area of the immunoreactive substance; and 3) number of pixels per gray level. Subsequently, we calculated the product of the number of pixels times the corresponding gray level; this value, named "total immunoreactivity," is considered a relative quantitative evaluation of the antigen content (20). We also calculated immunoreactivity per unit area and per structure. Five windows were measured in each rat.

\section{Statistical Analysis}

In the functional studies, mean values for experimental and control groups (mean \pm SEM) were compared by $t$ test after analysis of variance. A probability of $p<0.05$ (two-tailed) was taken to indicate a significant difference among groups.

In the morphologic studies, the significance of differences among groups was calculated by the Kruskall Wallis H-test.

\section{RESULTS}

Growth rate. Until postnatal d 4, there were no differences in growth rate among experimental groups. Between postnatal d 5 and 11, GHRH-Ab-treated rats had a growth rate significantly lower than NRS-treated rats.

GH treatment increased body weight gain in NRStreated pups and prevented the reduction in growth rate induced by GHRH-Ab. In NRS + GH-treated pups, the growth-promoting effect of $\mathrm{GH}$ became evident starting from postnatal d 6 , when their growth curve diverged significantly from that of pups given NRS alone. In GHRH-Ab-treated pups, substitutive GH therapy completely counteracted the growth inhibitory effect of GHRH-Ab, so that no difference between their body weight and that of NRS-treated pups was observed (Fig. 1).

Pituitary weight and GH content. Both the absolute and relative (\% body weight) weight of the pituitary gland were significantly reduced by GHRH-Ab treatment. Administration of GH did not modify these indices in NRSand GHRH-Ab-treated pups (Table 1).

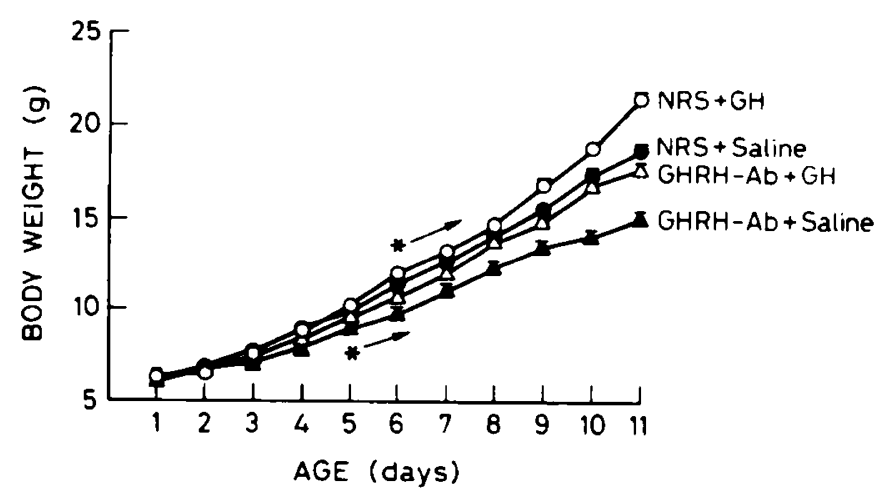

Figure 1. Changes in body weight with age in pups given NRS or $\mathrm{GHRH}-\mathrm{Ab}$ and saline or GH replacement therapy. From the asterisks and following the arrows, values are significantly different $(p<0.01)$ from those of NRS+saline-treated pups.
In rats given GHRH-Ab, irrespective of concomitant GH treatment, the total pituitary GH content, but not the $\mathrm{GH}$ concentration $(\mu \mathrm{g} / \mathrm{mg}$ gland), was reduced (Table 1$)$.

Effect of acute GHRH. Baseline plasma GH concentrations were significantly lower in GHRH-Ab-treated than in NRS-treated rats. GH treatment did not modify baseline plasma GH concentrations in NRS-treated pups but further reduced plasma GH levels in GHRH-Ab-treated pups (Table 2).

A single dose of GHRH did not raise plasma GH concentrations in GHRH-Ab-treated pups. Administration of hGH inhibited the GH response to the GHRH challenge in NRS-treated pups but partially restored it in GHRH-Ab-treated pups (Table 2).

Plasma IGF-I concentrations. Circulating IGF-I concentrations were lower in GHRH-Ab-treated pups than in NRS-treated ones. Administration of GH increased significantly plasma concentrations of IGF-I in NRS-treated pups and restored them to normal in GHRH-Ab-treated pups (Table 2).

Pituitary GH gene expression. When total RNA was subjected to Northern blot hybridization, GH mRNA was detected as a single 800-bp band.

Pituitary GH mRNA levels were significantly $(p<$ $0.01)$ reduced in GHRH-Ab-treated pups $(-54.6 \pm 2.0 \%$ versus NRS-treated group). Administration of GH did not modify pituitary GH mRNA levels in GHRH-Ab-treated pups $(-51.5 \pm 1.5 \%$ versus NRS-treated pups) (Fig. 2).

Pituitary SS binding. SS receptor binding was significantly lower in the pituitary glands of GHRH-Ab-treated pups than in those of NRS-treated animals. Administration of GH did not modify pituitary SS binding in NRStreated pups but restored it to normal in GHRH-Abtreated pups (Table 3 ).

Hypothalamic GHRH and SS gene expression. Increased hypothalamic GHRH mRNA levels and decreased SS mRNA levels were present in GHRH-Ab-treated pups (Table 4). Administration of GH did not modify GHRH and SS gene expression in either NRS- or GHRH-Abtreated pups (Table 4).

Morphometry, densitometry, electron microscopy, and immunocytochemistry. The number of pituitary GH-labeled structures was lower in pups treated with GHRH$\mathrm{Ab}+\mathrm{GH}$ than in those given NRS $+\mathrm{GH}$ (Fig. $3 A$ and $C$; Table 5). In contrast, the total immunoreactivity per unit surface was increased, although not significantly, in $\mathrm{GHRH}-\mathrm{Ab}+\mathrm{GH}$-treated compared with GH- or GHRH$A b$-treated pups (Table 5). In the GHRH-Ab+GHtreated group, the immunoreactivity was confined to the cell periphery (Fig. $3 C$ ).

The number of PRL-labeled structures was increased in $\mathrm{GH}$ - and GHRH-Ab+GH-treated pups, whereas the PRL immunoreactive area and the total immunoreactivity were increased only in the GHRH-Ab+GH group (Table 6).

No cell was labeled by the antiproliferating cell nuclear antigen immunocytochemical reaction. 
Table 2. Basal and GHRH-stimulated GH levels and circulating IGF-I concentrations in II-d-old pups given NRS or $G H R H-A b$ and saline or $G H$ replacement therapy

\begin{tabular}{|c|c|c|c|}
\hline \multirow[b]{2}{*}{ In vivo treatment } & \multicolumn{2}{|c|}{$\mathrm{GH}(\mathrm{ng} / \mathrm{mL})^{*}$} & \multirow[b]{2}{*}{$\mathrm{IGF}-\mathrm{I}^{*}(\mathrm{ng} / \mathrm{mL})$} \\
\hline & Basal & GHRH & \\
\hline NRS + saline & $11.5 \pm 1.0$ & $20.9 \pm 3.9 \dagger$ & $80.9 \pm 17.9$ \\
\hline NRS + GH & $10.8 \pm 1.1$ & $15.5 \pm 3.1$ & $119.8 \pm 17.1 \ddagger$ \\
\hline GHRH-Ab + saline & $4.7 \pm 0.6 \S$ & $5.0 \pm 0.9 \S$ & $34.1 \pm 7.9 \$$ \\
\hline $\mathrm{GHRH}-\mathrm{Ab}+\mathrm{GH}$ & $3.0 \pm 0.2+\S$ & $9.4 \pm 1.7+\$$ & $70.6 \pm 15.6 \dagger$ \\
\hline
\end{tabular}

* Hormone concentrations determined $24 \mathrm{~h}$ after the last GH treatment.

$+p<0.01$ is respective basal value.

$\ddagger p<0.05$ is NRS + saline value and $p<0.01$ is GHRH-Ab + saline value.

$\$ p<0.01$ is NRS + saline value.

By electron microscopy, somatotroph cells from pups treated with GHRH-Ab+GH had small and marginated granules and abundant rough endoplasmic reticulum (Fig. $3 B$ and $D$ ). This finding was obtained on the conventionally postfixed preparations and confirmed by the study of comparable cells on GH-labeled thin sections.

\section{DISCUSSION}

Earlier reports suggested that GH cannot affect growth in the immediate postnatal period of several mammals (21) despite its very high concentrations in the circulation at this age period (22-24). However, in a previous study (1) we showed that in the rat passive immunization against GHRH during the early postnatal period has profound and long-term effects on subsequent somatic growth and somatotropic function. Partial pituitary dependence of growth, even at the earliest neonatal stage,

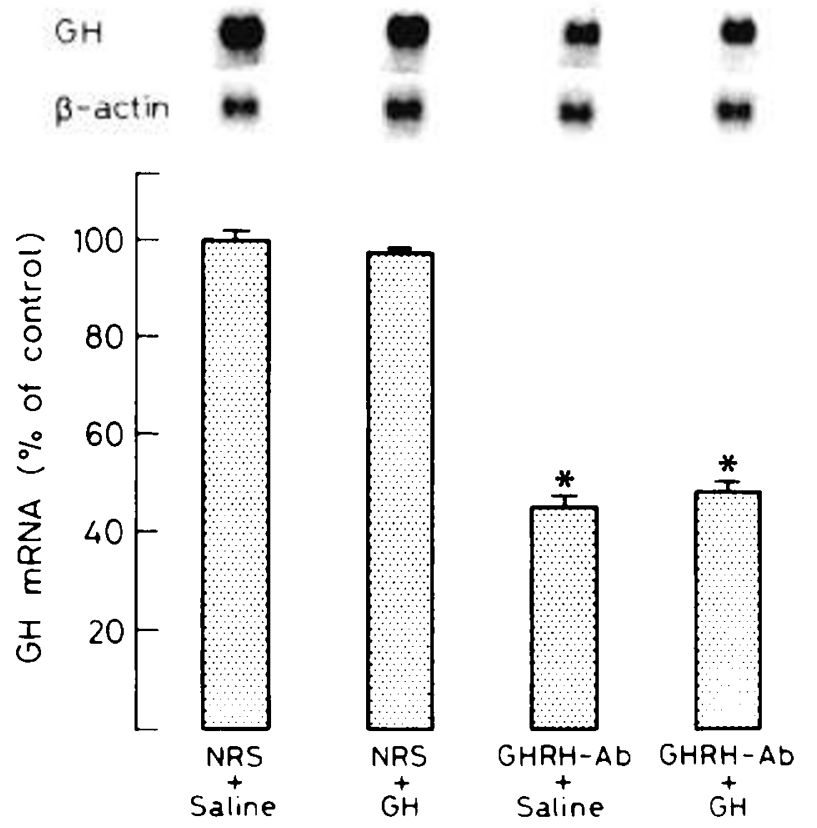

Figure 2. GH mRNA levels in pups given NRS or GHRH-Ab and saline or GH replacement therapy. The upper panel shows representative Northern blot hybridization signals from each experimental group (20 $\mu \mathrm{g}$ total mRNA/lane). The hybridization patterns for rat $\beta$-actin are also shown. The lower panel shows the mean \pm SEM of all the observations (four per group). ${ }^{*}, p<0.01$ is NRS + saline and $\mathrm{NRS}+\mathrm{GH}$ values. has also been evidenced more recently (25-27). In the present study, the ability of GH replacement therapy to reverse some defective indices of somatotropic function in GHRH-deprived 10-d-old rats reinforces the view that somatic growth is pituitary dependent very early in the postnatal period.

The most overt effect of GH replacement therapy was its ability to increase body weight gain in NRS-treated rats and restore to normal the defective growth rate of GHRH-Ab-treated rats. The dose used was selected based on its capacity to restore weight gain in hypophysectomized rats (28).

Although administration of $\mathrm{GH}$ also increased significantly plasma levels of IGF-I both in control and in GHRH-Ab-treated rats, the current data do not allow us to address the question of whether the growth-promoting effects of GH were mediated by the increased plasma IGF-I levels. It has been shown that, in the rat, a poor

Table 3. Autoradiographic evaluation of $\left.\right|^{125} I / T y$ - $1-S S$ binding to pituitary glands from 11-d-old pups given NRS or $G H R H-A b$ and saline or $G H$ replacement therapy

\begin{tabular}{lcc}
\hline & \multicolumn{2}{c}{ [' ${ }^{12 S}$ I]Tyr-1-SS concentration* } \\
\cline { 2 - 3 } In vivo treatment & $0.4 \mathrm{nM}$ & $0.8 \mathrm{nM}$ \\
\hline NRS + saline & $134.2 \pm 9.1$ & $361.2 \pm 15.3$ \\
NRS + GH & $177.3 \pm 21.5$ & $439.5 \pm 51.9$ \\
GHRH-Ab + saline & $23.0 \pm 10.8 \dagger$ & $232.9 \pm 46.9 \ddagger$ \\
GHRH-Ab + GH & $76.1 \pm 11.4 \S$ & $514.1 \pm 39.3 \S$ \\
\hline
\end{tabular}

* Results are expressed as arbitrary densitometry units; each value is the mean \pm SEM of five determinations made in quadruplicate.

$+p<0.01$ vs NRS + saline value.

$\ddagger p<0.05$ vs NRS + saline value.

$\S p<0.01 v s$ GHRH-Ab + saline value.

Table 4. GHRH and SS gene expression in 11-d-old pups given NRS or GHRH-Ab and saline or $G H$ replacement therapy

\begin{tabular}{lcc}
\hline In vivo treatment & $\begin{array}{c}\text { GHRH } \\
(\text { mRNA \%) }\end{array}$ & $\begin{array}{c}\text { SS } \\
(\text { mRNA \%) }\end{array}$ \\
\hline NRS + saline & 100 & 100 \\
NRS + GH & $+6.0 \pm 3.6$ & $-4.7 \pm 1.6$ \\
GHRH-Ab + saline & $+69.2 \pm 3.9 \dagger$ & $-44.7 \pm 2.2 \dagger$ \\
GHRH-Ab + GH & $+67.2 \pm 3.9 \dagger$ & $-41.1 \pm 2.4 \dagger$ \\
\hline
\end{tabular}

* Each value is the mean \pm SEM of five determinations; data are expressed as arbitrary densitometry units.

$\dagger p<0.01$ is NRS + saline and NRS + GH values. 

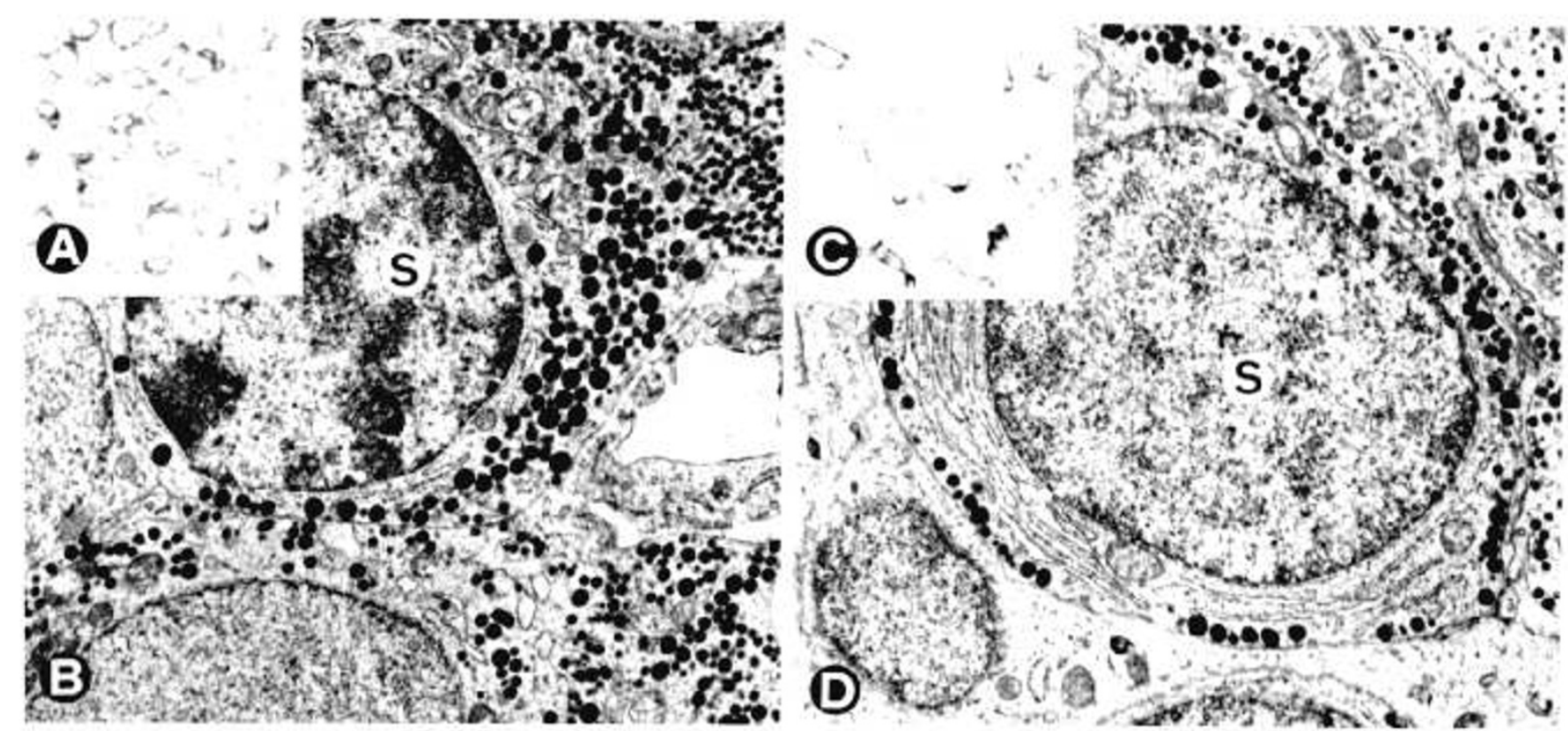

Figure 3. Somatotropes $(S)$ of $\mathrm{NRS}+\mathrm{GH}(A$ and $B)$ and GHRH-Ab+GH-treated pups $(C$ and $D) . A, C$ : light microscopy, anti-GH alkaline phosphatase reaction, $330 \times ; B, D$ : conventional electron microscopy, $7000 \times$. The cells from GHRH-Ab+GH-treated pups are less numerous and have smaller secretory granules than those of NRS+GH-treated pups; the granules are marginated and the rough endoplasmic reticulum cisternae abundant.

correlation exists between circulating IGF-I levels and somatic growth (29). It is now hypothesized that IGF-I stimulates organ and skeletal growth via autocrine/ paracrine fashion $(29,30)$. In this vein, it is important to recall that subcutaneous infusion of IGF-I does not stimulate body growth in normal young adult (31) or neonatal hypophysectomized (29) rats, and furthermore, immunoneutralization of IGF has no effect on growth in normal pups (25). A stimulatory effect of IGF-I on body weight gain and tibial epiphyseal width has been reported in prepubertal male rats (31).

GH synthesis is reduced in adult rats passively immunized with GHRH-Ab (32) or after chemical (33) or surgical (32) destruction of the mediobasal hypothalamus. This was also observed in 10-d-old pups given GHRH-Ab (1) and in the present study, where decreased GH gene expression was observed in the GHRH-Ab-treated pups. Under our experimental conditions, administration of GH did not modify GH synthesis in either NRS- or GHRH-Ab-treated rats.
Pituitary weight and GH content were lower in GHRHAb-treated than in NRS-treated pups, but pituitary GH concentrations were not different. Therefore, the finding in our study of unaltered GH concentrations despite a decreased pituitary GH synthesis probably indicates a defect not only in GH synthesis, but also in GH release. Administration of GH to GHRH-Ab-treated pups failed to alter any of these pituitary indices.

GH treatment of NRS-treated rats, in agreement with previous results (34), did not reduce basal GH concentrations but inhibited, although not completely, the GH responsiveness to GHRH. However, GH treatment in GHRH-Ab-treated rats did reduce basal GH levels while at the same time increasing the GH response to GHRH. Thus, $\mathrm{GH}$ feedback effects are significantly modulated by the underlying GHRH and GH environment.

The inhibitory effect of GH in GHRH-deficient rats could be attributed to a feedback effect elicited by IGF-I at the pituitary level. IGF-I has been shown to participate in a negative feedback loop to suppress not only GH

Table 5. Morphometry and immunodensitometry of somatotropic cells from 11-d-old pups given NRS or GHRH-Ab and saline or GH replacement therapy*

\begin{tabular}{lccccc}
\hline In vivo treatment & $\begin{array}{c}\text { No. of structures } \\
(\mathrm{A})\left(\times 10^{-1}\right)\end{array}$ & $\begin{array}{c}\text { Area }(\mathrm{B}) \\
\left(\mu \mathrm{m}^{2} \times 10^{-1}\right)\end{array}$ & $\begin{array}{c}\text { TI }(\mathrm{C}) \\
\left(\times 10^{-3}\right)\end{array}$ & C/A & C/B \\
\hline NRS + saline & $263 \pm 43.1$ & $360 \pm 97.5$ & $370 \pm 105.0$ & $163.9 \pm 62.2$ & $101.0 \pm 1.3$ \\
NRS + GH & $331 \pm 13.2$ & $335 \pm 119.5$ & $335 \pm 120.6$ & $108.5 \pm 39.0$ & $99.3 \pm 0.6$ \\
GHRH-Ab + saline & $273 \pm 40.1$ & $529 \pm 53.7$ & $522 \pm 51.7$ & $200.4 \pm 18.8$ & $98.7 \pm 1.0$ \\
GHRH-Ab + GH & $228 \pm 32.8 \dagger$ & $364 \pm 59.9$ & $376 \pm 63.2$ & $166.4 \pm 14.3$ & $103.1 \pm 0.7 \dagger \neq$ \\
\hline
\end{tabular}

* Values are means (sum of five windows per rat) \pm SEM. TI, total immunoreactivity. The same description applies to Table 6 . See Methods for further details.

$\dagger p<0.05 v s \mathrm{NRS}+\mathrm{GH}$ value.

$\ddagger p<0.01$ vs GHRH-Ab + saline value. 
Table 6. Morphometry and immunodensitometry of lactotropic cells from 11-d-old pups given NRS or GHRH-Ab and saline or GH replacement therapy

\begin{tabular}{lccccc}
\hline In vivo treatment & $\begin{array}{c}\text { No. of structures } \\
(\mathrm{A})\left(\times 10^{-1}\right)\end{array}$ & $\begin{array}{c}\text { Area }(\mathrm{B}) \\
\left(\mu \mathrm{m}^{2} \times 10^{-1}\right)\end{array}$ & $\begin{array}{c}\text { TI }(\mathrm{C}) \\
\left(\times 10^{-3}\right)\end{array}$ & C/A & C/B \\
\hline NRS + saline & $60 \pm 10.9$ & $20.2 \pm 5.2$ & $22.0 \pm 5.8$ & $34.5 \pm 4.4$ & $104.4 \pm 0.7$ \\
NRS + GH & $119 \pm 19.9^{*}$ & $50.3 \pm 14.8$ & $54.6 \pm 16.5$ & $45.3 \pm 9.4$ & $107.8 \pm 0.8$ \\
GHRH-Ab + saline & $113 \pm 23.1$ & $42.6 \pm 11.7$ & $46.4 \pm 12.8$ & $37.6 \pm 3.9$ & $108.6 \pm 0.5$ \\
GHRH-Ab + GH & $180 \pm 33.3 \dagger$ & $50.5 \pm 12.6^{*}$ & $53.9 \pm 13.6 \dagger$ & $28.7 \pm 1.8$ & $106.4 \pm 0.6$ \\
\hline
\end{tabular}

${ }^{*} p<0.05$ vs NRS + saline value.

$+p<0.01$ vs NRS + saline value.

release (35) but also GH gene expression (36) and transcription (37). Fetal and neonatal pituitary cells in vitro are already sensitive to this pituitary-directed inhibitory action of IGF-I (38).

A direct effect of GH on the pituitary to inhibit its own secretion is not likely, at least in adult rats (39). Also, the possibility that $\mathrm{GH}$ per se $(40,41)$ or through circulating or in situ IGF-I $(42,43)$ may act at the hypothalamic level is unlikely (see below).

We have previously shown (1) and confirmed in this study that pups immunized with GHRH-Ab are completely unresponsive to exogenous GHRH immediately posttreatment. Ironically, in pups undergoing combined $\mathrm{GHRH}-\mathrm{Ab}$ and $\mathrm{GH}$ treatment, whose $\mathrm{GH}$ release should be even worse than that of rats treated with GHRH-Ab alone, the GH response to GHRH was partially preserved. Some morphologic features of the somatotrophs of these pups, denoting the existence of an unexpectedly high cellular activity, support this finding. In fact, the GH immunoreactivity per unit cytoplasm area was more intense and the secretory granules were smaller in the cells of GHRH-Ab+GH-treated pups than in somatotrophs of the pups treated with GHRH-Ab or $\mathrm{GH}$ alone, thus indicating a higher concentration of $\mathrm{GH}$ molecules inside the secretory granules. The marginal location of the $\mathrm{GH}$ secretory granules could explain the higher GH responsiveness to GHRH, because marginated granules can be rapidly released (44). Also, the abundant rough endoplasmic reticulum suggests an intense cytoplasmic activity, which, however, did not lead to cell proliferation, as shown by the absence of mitotic activity demonstrated with the antiproliferating cell nuclear antigen immunocytochemical reaction.

Pituitary GH-immunoreactive structures were fewer but the PRL-immunoreactive structures more numerous than in the corresponding control group. This seems to indicate 1) a particularly strong suppression of the GHRH tone, because it is known that GHRH inhibits the proliferation of mammotrophs in vitro (45), and 2) a possible shift of the somatotroph population toward mammotrophs (46).

GH replacement therapy in the NRS-treated rats suppressed the GH response to GHRH. This is in agreement with findings obtained in adult rats (47) and GH-deficient children $(48,49)$.

Overall, results dealing with basal and GHRH-stimulated $\mathrm{GH}$ secretion in pups given combined GHRH-Ab and
GH treatment do not allow a definite conclusion. Measurement of pituitary GHRH receptors may provide meaningful information in this context. It is noteworthy, however, that evaluation of the density of SS pituitary receptors, although confirming that GHRH-Ab treatment markedly reduced this index of somatotropic function (1) and showing that GH per se did not affect it, disclosed, most importantly, that $\mathrm{GH}$ treatment counteracted the inhibitory effect of GHRH-Ab. We do not know whether the protective action of $\mathrm{GH}$ on pituitary SS binding may account for the partial preservation of the GH-releasing action of GHRH in these pups. However, regardless of this problem, it is apparent that in GHRH-Ab-treated pups the decreased SS binding is not due to the lack of GHRH.

Administration of GH in both GHRH-Ab-treated and control rats failed to modify baseline gene expression of GHRH and SS. This finding is in contrast to our earlier study in which we observed that a 4-fold higher dose of $\mathrm{GH}$, administered under the same experimental conditions, decreased hypothalamic GHRH gene expression in intact pups (34). Consequently, it cannot be ruled out that greater $\mathrm{GH}$ doses or a longer treatment period may modify hypothalamic gene expression of GHRH and SS. It is noteworthy that replacement therapy with $\mathrm{GH}$, at the dose presently used, did not affect significantly GHRH and SS gene expression in prepubertal hypothyroid rats (41) and that $\mathrm{GH}(75 \mu \mathrm{g} / \mathrm{rat}$, twice daily, s.c.) also failed to decrease the elevated GHRH mRNA levels in adult hypophysectomized rats.

In conclusion, in GHRH-deprived pups, a GH replacement therapy counteracts the disrupting effect of the passive immunization on growth rate, IGF-I production, and pituitary SS binding and improves the ability of the gland to respond to an acute GHRH challenge. GH replacement fails to revert to normal the altered gene expression of hypothalamic GHRH and SS. Thus, the action of GH early postnatally appears to be mainly directed at the pituitary, although the underlying mechanism(s) has yet to be clarified.

\section{REFERENCES}

1. Cella SG, Locatelli V, Mennini T, Zanini A, Bendotti C, Forloni GL, Fuma. galli G, Arce VM, De Gennaro Colonna V, Wehrenberg WB, Muller EE 1990 Deprivation of growth hormone-releasing hormone early in the rat's neonatal life permanently affects somatotropic function. Endocrinology 127:1625-1634

2. Wehrenberg WB, Voltz DM, Cella SG, Müller EE, Gaillard RC 1992 Longterm failure of compensatory growth in rats following acute neonatal passive immunization against growth hormone-releasing hormone. Neuroendocrinology $56: 509-515$ 
3. Wehrenberg WB, Bloch B, Phillips BJ 1984 Antibodies to growth hormonereleasing factor inhibit somatic growth. Endocrinology $115: 1218-1220$

4. Wehrenberg WB 1986 The role of growth hormone-releasing factor and somatostatin on somatic growth in rats. Endocrinology 118:489-494

5. Spiess J, Rivier J, Vale W 1983 Characterization of rat hypothalamic growth hormone-releasing factor. Nature 303:532-535

6. Benoit R, Bohlen P, Ling N, Brisken A, Esch F, Brazeau P. Ying SY, Guillemin R 1982 Presence of somatostatin-28-(1-12) in hypothalamus and pancreas. Proc Natl Acad Sci USA 79:917-921

7. Arsenijevic Y, Wehrenberg WB, Conz A, Eshkol A, Sizonenko PC, Aubert ML 1989 Growth hormone $(\mathrm{GH})$ deprivation induced by passive immunization against rat $\mathrm{GH}$-releasing factor delays sexual maturation in the male rat. Endocrinology 124:305(1-3059

8. Cella SG, Locatelli V. De Gennaro V, Wehrenberg WB, Muller EE 1987 Pharmacological manipulations of $\alpha$-adrenoceptors in the infant rat and ef fects on growth hormone secretion. Study of the underlying mechanisms of action. Endocrinology 120:1639-1643

9. Chomczynski P, Sacchi N 1987 Single-step method of RNA isolation by acid guanidium thiocyanate-phenol-chloroform extraction. Anal Biochem 162:156-159

10. McCarthy R, Plunkett LM 1987 Quantitative autoradiographic analysis of somatostatin binding sites in discrete areas of rat forebrain. Brain Res Bull $18: 29-34$

11. Morel G, Leroux P, Pellettier G 1985 Localization and characterization of somatostatin-14 and somatostatin-28 receptors in the rat pituitary as studied by slide-mounted frozen sections. Neuropeptides $6: 41-52$

12. De Gennaro Colonna V, Bertola G, Coco CB, Bifano M, Cocchi D, Maggi A, Muller EE 1990 Changes in the hypothalamic-pituitary somatotropic function of infant hypothyroid rats. Proc Soc Exp Biol Med 193:214-219

13. Cocilovo L, De Gennaro Colonna V. Zoli M, Biagini G. Settembrini BP, Muller EE, Cocchi D 1992 Central mechanisms subserving the impaired growth hormone secretion induced by persistent blockade of NMDA receptors in immature male rats. Neuroendocrinology 55:416-421

14. Schalch DS, Reichlin S 1966 Plasma growth hormone concentration in rat determined by radioimmunoassay: influence of sex, pregnancy, lactation. anesthesia, hypophysectomy and extrasellar pituitary transplant. Endocrinology $79: 275-280$

15. Rossi GL, Bestetti G 1983 Technical aspects in the study of pathologic lesions in the hypothalamus of the rat. In: Jones TC, Mohr U. Hunt RD (eds) Monographs on Pathology of Laboratery Animals. Endocrine System. Springer, Berlin, p 311

16. Bestetti GE, Reymond MJ, Perrin IV, Kniel PC. Lemarchand-Beraud T, Rossi GL 1987 Thyroid and pituitary secretory disorders in streptozocindiabetic rats are associated with severe structural changes of these glands. Virchows Arch B 53:69-78

17. Lloyd JM, Childs GV 1988 Differential storage and release of luteinizing hormone and follicle-releasing hormone from individual gonadotropes separated by centrifugal elutriation. Endocrinology 122:1282-1290

18. Connolly KM, Bogdanffy MS 1993 Evaluation of proliferating cell nuclear antigen (PCNA) as an endogenous marker of cell proliferation in rat liver: a dual-stain comparison with 5-bromo-2'-deoxyuridine. J Histochem Cytochem 41:1-6

19. Rossi GL, Bestetti GE, Galbiati E, Müller EE, Cocchi D 1991 Sexually dimorphic effects of aging on rat somatotropes and lactotropes. J Gerontol Biol Sci 46:B152-B158

20. Agnati LF, Fuxe K, Zoli M, Zini I, Harfstrand A, Toffano G, Goldstein M 1988 Morphometrical and microdensitometrical studies on phenylethanolamine- $\mathrm{N}$-methyltransferase and neuropeptide $\mathrm{Y}$-immunoreactive neurons in the rostral medulla oblongata of the adult and old male rats. Neuroscience 26:461-478

21. Glasscock GF, Nicoll CS 1981 Hormonal control of growth in the infant rat. Endocrinology 109:176-184

22. Rieutort, M 1974 Pituitary content and plasma levels of growth hormone in fetal and weanling rats. J Endocrinol 60:261-268

23. Gluckman PD, Higgins GC 1984 The regulation of fetal growth. In: Beard R. Nathanielsz P (eds) Fetal Physiology and Medicine. Marcel Dekker, New York, pp 511-518

24. Miller JD, Wright NM, Esparza A, Jansons R, Yang HC, Hahn H, Mosier Jr HD 1992 Spontaneous pulsatile growth hormone release in male and female premature infants. J Clin Endocrinol Metab 75:1508-1513

25. Spencer GSG, Robinson GM Dobbie P, Hodgkinson SC, Bass JJ 1992 Evidence of a role for growth hormone, but not for insulin-like growth factors 1 or 2, in growth of neonatal rat. J Endocrinol Invest (suppl 4) 15:83(abstr)

26. Glasscock GF, Gin KKL, Kim JD, Hintz RL, Rosenfeld RG 1991 Ontogeny of pituitary regulation of growth in the developing rat: comparison of effects of hypophysectomy and hormone replacement on somatic and organ growth, serum insulin-like growth factor-l (IGF-I) and IGF-II levels, and IGF-binding protein levels in the neonatal and juvenile rat. Endocrinolgy 128:1036-1039

27. Cella SG, Locatelli V, Broccia ML, Menegola E, Giavini E, De Gennaro Colonna V, Torsello A, Wehrenberg WB, Muller EE 1994 Long-term change of somatotrophic function induced by deprivation of growth hormonereleasing hormone during the fetal life of the rat. J Endocrinol 140:111-117

28. Chomezynski P, Downs TR, Frohman LA 1988 Feedback regulation of growth hormone $(\mathrm{GH})$-releasing hormone gene expression by $\mathrm{GH}$ in rat hypothalamus. Mol Endocrinol 2:23t-241

29. Glasscock GF, Hein AN, Miller JA, Hintz RL, Rosenfeld RG 1992 Effects of continuous infusion of insulin-like growth factor $I$ and II, alone and in combination with thyroxine or growth hormone, on the neonatal hypophy sectomised rat. Endocrinology 130:2013-2(16

30. Hizuka N, Sukegawa I, Takano K, Asakawa K, Orikawa R, Tsushima T, Shizume K 1987 Characterization of insulin-like growth factor I receptors on human erythroleukemia cell line (K-562 cells). Endocrinol Jpn 34:81-88

31. Zapf J, Hauri C, Waldvogel M. Futo E, Hasler H, Binz K, Cruler HP, Schmid C, Froesch ER 1989 Recombinant human insulin-like growth factor I induces its own specific carrier protein in hypophysectomized and diabetic rat. Proc Natl Acad Sci USA 86:3813-3817

32. Shakutsui S, Abe H. Chihara K 1989 GHRH treatment: studies in an animal model. Acta Paediatr Scand Suppl 349:101-107

33. Corder R, Saudan P, Mazlan M, McLcan C, Gaillard RC 1990 Depletion of hypothalamic growth hormone-releasing hormone by neonatal monosodium glutamate treatment reveals an inhibitory effect of beta-methasone on growth hormone secretion in adult rats. Neuroendocrinology 51:85-92

34. Cella SG, De Gennaro Colonna V. Locatelli V. Moiraghi V, Loche S, Wehrenberg WB, Müller EE 1990 Growth hormone $(\mathrm{GH})$ autofeedback action in the neonatal rat: involvement of GH-releasing factor (GHRF) and somatostatin. J Endocrinol 124:199-295

35. Ceda GP, Hoffman AR, Silverberg GD. Wilson DM, Rosenfeld RG 1985 Regulation of growth hormone release from cultured human pituitary adenomas by somatomedins and insulin. J Clin Endocrinol Melab 60):1204-1209

36. Yamashita S, Weiss M, Melmed S 1986 Insulin-like growth factor I regulates growth hormone secretion and messenger ribonucleic acid levels in human pituitary tumor cells. J Clin Endocrinol Metab 63:730-735

37. Yamashita S, Melmed S 1987 Insulin-like growth factor I regulation of growth hormone gene transcription. J Clin Invest 79:449-457

38. Silverman BL, Bettendorf M, Kaplan S, Grumbach MM, Miller WL 1984 Regulation of growth hormone (GH) secretion by GH-releasing factor, somatostatin, and insulin-like growth factor $I$ in ovine fetal and neonatal pituitary cells in vitro. Endocrinology 124:84-89

39. Richman RA, Weiss JP, Hochberg Z, Florini JR 1981 Regulation of growth hormone release: negative feedback in rat pituitary cells. Endocrinology 108:2287-2292

40. De Gennaro Colonna V, Cattaneo E, Cocchi D, Muller EE, Maggi A 198 Growth hormone regulation of growth hormone-releasing hormone gene ex pression. Peptides 9:985-988

41. De Gennaro Colonna V, Bertola G, Coeo CB. Bifano M, Cocchi D, Maggi A Muller EE 1991 Hypothalamic pituitary somatotropic function in prepubertal hypothyroid rats: effect of growth hormone replacement therapy. Proc Soc Exp Biol Med 196:4.32-4.37

42. Berelowitz M, Szabo M, Frohman LA, Firestone S, Chu L, Hintz RL 1981 Somatomedin- $C$ mediates growth hormone negative feedback by effects on both the hypothalamus and the pituitary. Science 212:1279-1281

43. Wood TL, Berelowitz M, Gelato MC, Roberts CT, LeRoith D, Millard WJ, McKelvy JF 1991 Hormonal regulation of rat hypothalamic neuropeptide mRNAs: effect of hypophysectomy and hormone replacement on growthhormone-releasing factor, somatostatin and the insulin-like growth factors. Neuroendocrinology 53:298-305

44. Lewis CE, Morris JF, Fink G 1985 The role of microfilaments in the priming effect of LH-releasing hormone: an ultrastructural study using cytochalasin B. J Endocrinol 106:211-218

45. Shinkai T, Ooka H, Noumura T 1991 Growth hormone-releasing factor (GRF) suppresses the in vitro proliferation of mammotrophs from the adult rat. Neurosci Lett 23:13-16

46. Porter TE, Wiles CD, Frawley LS 1991 Evidence for bidirectional interconversion of mammotropes and somatotropes: rapid reversion of acidophilic cell types to pregestational proportions after weaning. Endocrinology 129:12151220

47. Sato M, Chihara K, Kita T, Kashio Y, Okimura Y, Kitajima N, Fujita T 1989 Physiological role of somatostatin-mediated autofeedback regulation for growth hormone: importance of growth hormone in triggering somatostatin release during a trough period of pulsatile growth hormone release in conscious male rats. Neuroendocrinology 50:139-151

48. Ross RJM, Borges F, Grossman A, Smith R, Nhagafoong L, Rees LH, Savage MO, Besser GM 1987 Growth hormone pretreatment in man blocks the response to growth hormone-releasing hormone: evidence for a direct effect of growth hormone. Clin Endocrinol 26:117-123

49. Rosenbaum M. Loche S, Balzano S, Gertner JM 1988 Short-term met-hGH infusion inhibits somatotroph response to growth hormone releasing hormone $(1-44)$. Metabolism 37:131-135 